\title{
GC-MS ANALYSIS AND BIOACTIVE PROPERTIES OF ZINGIBERIS RHIZOMA ESSENTIAL OIL
}

\author{
LAURA BUCUR $^{1 *}$, ELIS IONUS ${ }^{2 *}$, GEORGETA MOISE ${ }^{3 \#}$, CERASELA GÎRD ${ }^{4 \#}$, VERGINICA \\ SCHRÖDER $^{5}$
}

\author{
${ }^{1}$ Pharmacognosy Department, Faculty of Pharmacy, "Ovidius" University of Constanța, Romania \\ ${ }^{2}$ Organic Chemistry Department, Faculty of Pharmacy, "Ovidius" University of Constanța, Romania \\ ${ }^{3}$ Scient Research Centre for Instrumental Analysis, 1 Petre Ispirescu Street, Tâncăbeşti, Romania \\ ${ }^{4}$ Pharmacognosy Department, Faculty of Pharmacy, "Carol Davila” University of Medicine and Pharmacy, Bucharest, Romania \\ ${ }^{5}$ Cellular and Molecular Biology Department, Faculty of Pharmacy, "Ovidius” University of Constanța, Romania
}

*corresponding author: elis.ionus@drd.umfcd.ro

${ }^{\#}$ Authors with equal contribution.

Manuscript received: November 2019

\begin{abstract}
Ginger (Zingiber officinalis Roscoe) has been, from the past until now, one of the most worldwide cultivated aromatic plants. The fresh or dried underground ginger rhizome is used in medicinal purposes, which the European Pharmacopoeia presents as Zingiberis rhizoma. The essential oil obtained from ginger, available on the Romanian market, was prepared using the official method with the Neo-Clevenger apparatus. The amount of $1.925 \%(\mathrm{v} / \mathrm{m}) \pm 0.049$ was extracted, which is in accordance with the reference standards of the European Pharmacopoeia. The GC-MS analysis of essential oil composition revealed the presence of camphene (32.79\%), eucalyptol (24.32\%), $\alpha$-pinene $(18.05 \%)$ and zingiberene $(1.25 \%)$. Ginger essential oil has antioxidant properties with an IC50 value of $30.72 \mu \mathrm{L} / \mathrm{mL}$ in different acetone dilutions. The antifungal properties highlighted on isolated stems from public spaces (Fonsecaea sp. and Penicillium chrysogenum) may justify the use of ginger essential oil as an agent that prevents the exposure of the population to pathogens.
\end{abstract}

\section{Rezumat}

Ghimbirul (Zingiber officinalis Roscoe) a fost şi este una dintre cele mai cultivate plante aromate din lume. În scop medicinal, de la ghimbir se folosește rizomul, proaspăt sau uscat, pe care Farmacopeea Europeană îl prezintă în monografia Zingiberis rhizoma. Uleiul volatil obținut din ghimbirul comercializat pe piața din România, prin metoda oficinală, cu aparatul Neo-Clevenger, este în cantitate de 1,925\% (v/m) $\pm 0,049$, ceea ce corespunde prevederilor Farmacopeei Europene, care menționează un conținut de minim 1,5\% (v/m). Analiza GC-MS a uleiului volatil a pus în evidență prezența camfenului $(32,79 \%)$, eucaliptolului $(24,32 \%)$, $\alpha$-pinenului $(18,05 \%)$ și zingiberenului $(1,25 \%)$. Uleiul volatil de ghimbir prezintă proprietăți antioxidante cu valoarea IC 50 a diluțiilor, în acetonă, de $30,72 \mu \mathrm{L} / \mathrm{mL}$. Proprietățile antifungice puse în evidență pe tulpini izolate din spațiile publice (Fonsecaea sp. și Penicillium chrysogenum) pot justifica utilizarea uleiului volatil de ghimbir ca agent de prevenire a expunerii populației la agenți patogeni.

Keywords: Zingiberis rhizome, essential oil, GC-MS analysis, antifungal activity, cultural heritage preservation

\section{Introduction}

Ginger (Zingiber officinalis Roscoe) has been and still is one of the world's most cultivated aromatic plants, being recognized by Asians since the first century as a medicinal herb with rapid effects.

Ginger has nearly 500 identified compounds, many of which have known biological activity, acting in a complementary way to produce profound biological benefits, such as alleviating digestive disorders, treating respiratory problems, improving blood circulation, fighting inflammations and infections, etc.

In a recent study, Amalraj et al. (2020) presented the 40 major components in the ginger essential oil, among which there are: $\alpha$-zingiberene, $\beta$-cedrene, $\alpha$ curcumene, $\beta$-bisbolene, $\beta$-sesquiphellandrene, E- $\beta$ farnesene, $\beta$-panasinsene and others. The essential oil had significant antibacterial activity on Bacillus cereus, Staphylococcus aureus, Escherichia coli and Salmonella typhimurium [2].

Mi $\mathrm{H}$ et al. (2016) indicated that ginger essential oil could be used as a radical scavenger in the food industry due to the antioxidant activity of its phenolic components (gingerol, paradol, shogaol etc.) [25]. Bonilla et al. (2018) showed that the antioxidant activity takes place when ginger essential oil is incorporated in different film formulations. Therefore, the active film might be used as food packaging [7].

Sharifi-Rad et al. (2017) reported some biological properties of ginger essential oil with $\alpha$-zingiberene as the major component in an evaluation of the Zingiber genus, showing that it has antibacterial, antifungal and antioxidant activity. Many in vitro studies demonstrated 
the antimicrobial potential of Zingiber plant extracts against both Gram-positive (Bacillus cereus and Staphylococcus aureus) and Gram-negative (Escherichia coli, Salmonella typhi, Pseudomonas aeruginosa and Klebsiella pneumonia) bacteria. The essential oil also exhibited significant antifungal activity against $C$ andida glabrata, C. albicans and Aspergillus niger. These results suggest that the essential oil of the Zingiber plant could be used in the treatment of many bacterial and fungal diseases as well as in food preservation as natural preservatives [37].

Baldin et al. demonstrated the antimycobacterial activity of ginger essential oil against Mycobacterium tuberculosis, Mycobacterium boletti, Mycobacterium smegmatis, Mycobacterium abscessus, Mycobacterium chelonae and Mycobacterium massiliense. The evaluation of the 11 ginger essential oil fractions revealed promising activity against Mycobacterium spp., with minimum inhibitory concentration (MIC) values between 31.25 and $125 \mu \mathrm{g} / \mathrm{mL}$ [5].

Traditional long-term use and numerous studies on ginger rhizomes have shown that this product is considered safe and that it has antioxidant properties. For medicinal purposes, the fresh or dried rhizome of ginger is used, and it is presented in the European Pharmacopoeia under the title Zingiberis rhizoma [47].

Classical GC coupled with mass spectrometry (GCMS) [8, 14] or gaseous injection (GC-MS-HS) [23] were used for the identification and quantification of chemical constituents in essential oils.

This study presents a new perspective on the benefits of ginger essential oil as a solution with antifungal action. Using ginger essential oil as an agent in the prevention of the exposure to pathogens in public spaces may prove helpful in public health policies. The bio-aerosols are a complex mixture of microorganisms and organic materials where thousands of species of microorganisms exist, and most have not been studied. Bioaerosols can induce illnesses in a variety of ways, can produce allergic reactions, infections and toxicity. The health effects of biological materials can vary substantially from person to person [22].

Studies have indicated an increased incidence of infections caused by emerging fungi, which shows there is a necessity to research the potential use of essential oils as a new therapeutic alternative in the treatment of fungal infections, due to emerging drug resistance $[13,30]$.

Also, finding out more about the inhibition of microbes in indoor air or from surfaces is in the attention of air quality specialists [46].

In this work, the antifungal preliminary evaluation was carried out for two fungal strains (Fonsecaea sp. and Penicillium chrysogenum), which were isolated from the rock substrate of vestiges at the Archaeological Museum of Constanța, Romania. The importance of this study is conferred by the fact that it brings information about these fungi with infectious potential [34] from museum precincts.

Furthermore, this study could be considered as one of the first reports on the antifungal activity of Zingiber essential oil on the fungi strains isolated from archaeological exhibits in a museum. In a further study, our research will be continued and corelated with information on bioaerosols and surface quality and public health prevention measures.

\section{Materials and Methods}

The material used in this study was the essential oil obtained from the fresh rhizome of Zingiber officinale Roscoe purchased from the Romanian market, originally from China.

The rhizome was peeled and shredded before the preparation of the Zingiberis rhizoma plant product. The obtaining and the volumetric determination of essential oil was performed using the Neo-Clevenger method according to EP $9.0[27,47]$ and the GCMS analysis was performed with a Perkin Elmer Chromatograph.

$G C-M S$ analysis

The identification of volatile compounds in ginger essential oil was carried out using the GC-MS-HS technique, which involves gas-chromatographic screening with HS gas injection and detection by mass spectrometry. The identification of volatile compounds is based on the comparison of the spectra that have been obtained under predefined conditions with the SCIENT and NIST Wiley spectral libraries.

The method of analysis described below is the adaptation of the sample preparation method and the gas chromatographic method described in the literature [19, 28] using the selective mass detector for the purpose of detecting and identifying volatile compounds in ginger essential oil.

Used equipment: PerkinElmer Chromatographic system with mass spectrometry detection. The instrument is identified with the number E 65 and it is capable of providing optimum application conditions for the selected method. It is equipped with: Clarus 680 Gas Chromatograph; injection programmable injector in Split or Splitless mode; thermostatic oven with a gas chromatographic column (temperature range $40^{\circ} \mathrm{C}$ to $300^{\circ} \mathrm{C}$ ); Clarus SQ8T quadrupole mass spectrometer; and a capillary column of melted silica, ELITE-5MS, $\mathrm{L}=30 \mathrm{~m}, \Phi_{\mathrm{i}}=0.250 \mathrm{~mm}$, PerkinElmer.

Sample to be analysed: ginger essential oil obtained by steam distillation in the Neo-Clevenger apparatus.

The obtained chromatograms were screened to identify each present compound by comparison with the Scient and NIST-Wiley spectral libraries.

The peak selection criterion was the matching value of > 700 (the likelihood of retrieving the volatile compound by overlapping its spectra and the spectra from the library attached to the MS software). 
Antioxidant activity

The antioxidant capacity was determined by using a spectrophotometer (Jasco V-650) through the scavenger DPPH method [9, 11, 27, 32]. Scavenging activity was calculated as follow:

$$
\% \text { scavenger DPPH }=\frac{A_{\text {control }}-A_{\text {sample }}}{A_{\text {control }}} x 100
$$

where: $\mathrm{A}_{\text {control }}$ and $\mathrm{A}_{\text {sample }}$ are the absorbances at 517 $\mathrm{nm}$ for DPPH methanol solution and the samples, respectively.

The DPPH solution was prepared by dissolving DPPH in methanol to obtain an absorbance value of $0.8 \pm 0.02$. For the preparation of each sample, $0.1 \mathrm{~mL}$ of essential oil was diluted in acetone $(20 \mu \mathrm{L} / \mathrm{mL}$, $10 \mu \mathrm{L} / \mathrm{ml}, 5 \mu \mathrm{L} / \mathrm{mL}$ ) and was mixed with $3.9 \mathrm{~mL}$ of DPPH solution. The essential oil is not miscible with methanol, therefore acetone had to be used in order to dilute it. In other studies, Tween 20 was used as an oil-in-water emulsifier [33]. The mixtures were incubated in the dark at $25 \pm 2^{\circ} \mathrm{C}$ for $30 \mathrm{~min}$, then the absorbance was measured at $517 \mathrm{~nm}$ and compared with the absorbance of a blank (pure methanol) [21, 42].

The purple colour of the DPPH solution at $517 \mathrm{~nm}$ changed to pale yellow due to the appearance of the reduced form of the free radical after contact with the sample solution containing essential oil with free radical scavenging potential.

The IC50 (the dilution of essential oil that scavenges $50 \%$ of the free radical) was calculated in the Excel program by linear interpolation, using the generated equation: inhibition $=1.6675^{*}$ concentration -1.2187 , $\mathrm{R}^{2}=0.9939$.

\section{Antifungal activity}

The antifungal activity was determined by testing ginger essential oil on fungal strains (Fonsecaea sp. and Penicillium chrysogenum) isolated from rock substrate from vestiges at the Archaeological Museum of Constanța, Romania. The isolated strains were raised on Sabouraud agar and were used to inoculate and perform the disk diffusion method [20, 36, 26, 29]. The strains subcultures were separated on Sabouraud agar plates and incubated at $24-25^{\circ} \mathrm{C}$ for 2 - 5 days for Penicillium and 5 - 7 days for Fonsecaea. The fungal suspension and inoculum preparation $\left(10^{6}-10^{7} \mathrm{CFU} / \mathrm{mL}\right)$ were obtained from each fungal subculture [13] in sodium chloride solution (0.9\%) [17] and the concentration was verified in a haemocytometer chamber. The fungal suspension was dispersed on the whole surface on the Sabouraud agar plates with cotton sterile swabs [20]. A positive control plate containing only fungal suspension was also used. The control plates and samples medium were inoculated in similar conditions.

The essential oil was spread in equal volumes $(10 \mu \mathrm{L})$ on four filter paper discs with a diameter of $5 \mathrm{~mm}$, which were subsequently applied on the surface of
SDA medium inoculated with spores of fungal strains. The plates were covered with glass covers and were incubated at room temperature $\left(24 \pm 2^{\circ} \mathrm{C}\right)$ for 20 days. For each tested sample, the assessment of inhibitory activity was carried out in triplicate.

The evolution of the cultures was observed periodically, and the growth of the macroscopically visible colonies was recorded. The determination of the species was based on morphological criteria (colony features, pigmentation), hyphae and spores details identified in microscopic preparations [10, 34, 35].

The growth inhibition (\%) was evaluated on the fungal colonies' growth in the experimental plates compared to the control plates according to the formula:

$$
\text { Growth inhibitive performance }(\%)=\frac{C-S}{C} \times 100 \text {, }
$$

which shows the inhibition rate of fungus growth of the experimental samples and where: $\mathrm{c}-$ the number of the colonies from control plates; $\mathrm{s}-$ the number of the colonies from experimental plates; the evaluation and the colonies counting was corelated with the growth characteristics of the species.

The zone of inhibitory activity was recorded as the diameter of the clear zone and the medium values (between large diameter and small diameter) were used for analyses. [13, 20].

\section{Results and Discussion}

An amount of volatile oil of $1.925 \%(\mathrm{v} / \mathrm{w}) \pm 0.049$ was obtained from a quantity of $250-300 \mathrm{~g}$ of fresh Zingiberis rhizoma with a loss on drying of $91.40 \% \pm 0.51$.

The Zingiberis rhizoma plant product is of good quality, as it contains between 1 - 3\% essential oil, as mentioned in the literature data [1, 37], which falls within the specifications of the European Pharmacopoeia 9.0 edition of at least $15 \mathrm{~mL} / \mathrm{kg}$ [47].

The obtained essential oil is yellowish, with characteristic flavour and aroma and subunit density. Data from the literature describes the same features [24, 47]. The lemon scent of the preparation is due to the presence of geranial [24].

\section{$G C$ - $M S$ analysis}

Some of the compounds present in the GC-MS chromatogram (Figure 1) were identified using the data library of the device, with a match $>900$.

The 16 identified compounds with retention times and areas under curves are shown in Table I. Also, the percentage of each identified compound in the essential oil composition is reported. When considering the areas under the total curve, the highest percentage belongs to camphene (32.79\%), followed by eucalyptol $(24.32 \%)$ and $\alpha$-pinene $(18.05 \%)$. Zingiberene was found in a small amount, of $1.25 \%$. 


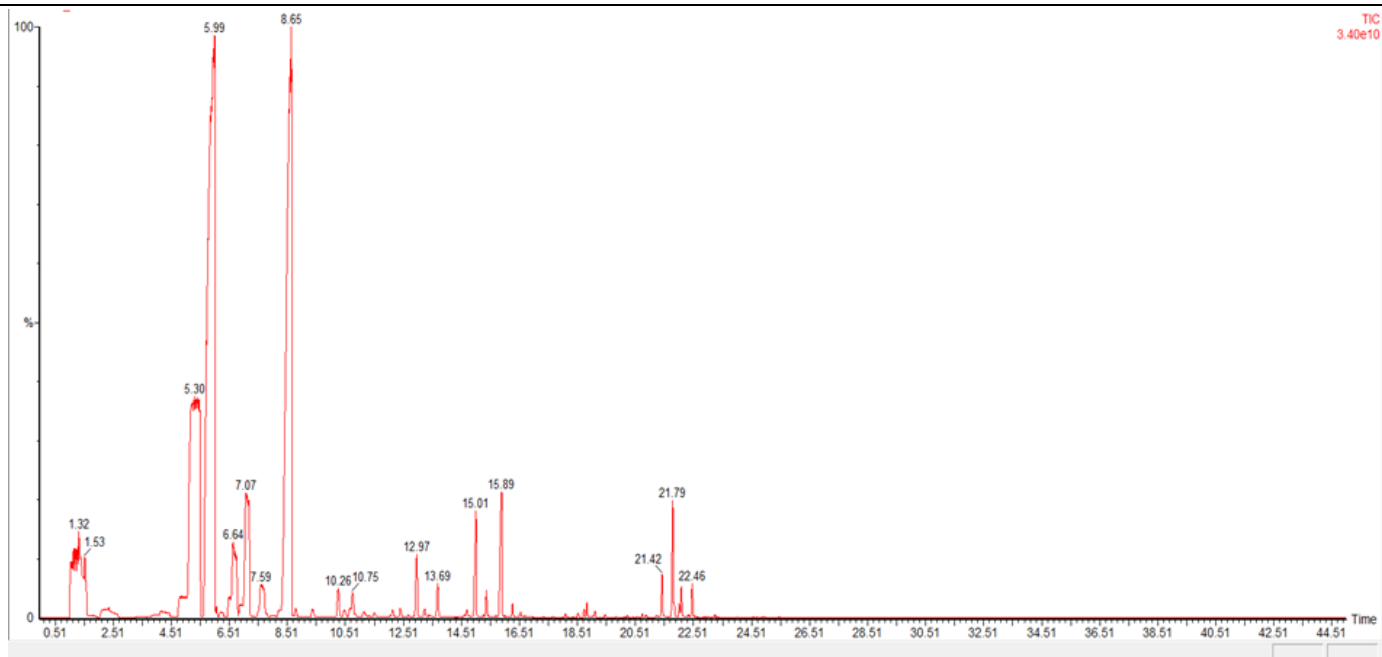

Figure 1.

Chromatogram GC-MS of essential oil of Zingiberis rhizome

Table I

The compounds identified in the essential oil of Zingiberis rhizoma

\begin{tabular}{|c|c|c|c|c|}
\hline No. & Compound name & RT (retention time) min & AUC (area under the curve) & $\%$ compound from total area \\
\hline 1 & $\alpha$-pinene & 5.3 & $4.90 \times 10^{9}$ & 18.05 \\
\hline 2 & camphene & 5.99 & $8.90 \times 10^{9}$ & 32.79 \\
\hline 3 & $\beta$-pinene & 6.64 & $0.80 \times 10^{9}$ & 2.95 \\
\hline 4 & $\beta$-myrcene & 7.07 & $1.30 \times 10^{9}$ & 4.79 \\
\hline 5 & $\alpha$-phellandrene & 7.59 & $0.30 \times 10^{9}$ & 1.11 \\
\hline 6 & eucalyptol & 8.65 & $6.60 \times 10^{9}$ & 24.32 \\
\hline 7 & $\alpha$-terpinolene & 10.26 & $0.12 \times 10^{9}$ & 0.44 \\
\hline 8 & linalol & 10.75 & $0.16 \times 10^{9}$ & 0.59 \\
\hline 9 & borneol & 12.97 & $0.24 \times 10^{9}$ & 0.88 \\
\hline 10 & cis-citral (neral) & 15.01 & $0.35 \times 10^{9}$ & 1.29 \\
\hline 11 & trans-citral (geranial) & 15.89 & $0.53 \times 10^{9}$ & 1.95 \\
\hline 12 & $\alpha$-curcumene & 21.42 & $0.12 \times 10^{9}$ & 0.44 \\
\hline 13 & zingiberene & 21.79 & $0.34 \times 10^{9}$ & 1.25 \\
\hline 14 & $\alpha$-farnesene & 22.01 & $0.32 \times 10^{9}$ & 1.18 \\
\hline 15 & farnesol & 22.08 & $0.76 \times 10^{9}$ & 2.80 \\
\hline 16 & cedrol & 22.46 & $0.76 \times 10^{9}$ & 2.80 \\
\hline \multicolumn{3}{|c|}{ Identified compounds } & $26.50 \times 10^{9}$ & 97.63 \\
\hline \multicolumn{3}{|c|}{ Total compounds } & $27.14 \times 10^{9}$ & 100 \\
\hline
\end{tabular}

The literature highlights the influence of many factors on the quantity and quality of ginger essential oil: pedoclimatic conditions, fresh or dry use [1] and extraction methods [24, 38].

Evans WC (2002) mentions the presence of camphene, phellandrene, curcumene, terpineol, borneol and citral in ginger essential oil [16], which are compounds that were also found in the sample analysed in the present study.

Mesomo et al. (2013) makes a comparison between the composition of essential oil obtained by steam distillation and the essential oil obtained by extraction with supercritical $\mathrm{CO}_{2}$. He mentions that the main constituent of essential oil obtained by steam distillation from dry ginger is camphene, which is similar to the findings in our study, or $\alpha$-curcumene if the fresh product is used. In ginger essential oil obtained by extraction with supercritical $\mathrm{CO}_{2}$ the major component is $\alpha$-zingiberene. The author also mentions the amount of $2.62 \%$ essential oil yielded after extraction with supercritical $\mathrm{CO}_{2}$, respectively $1.79 \%$ through the steam distillation method, which confirms the fact that the extraction method influences the quantity and quality of the obtained essential oil [18]. Our yield of essential oil obtained by steam distillation with the Neo-Clevenger apparatus was $1.925 \%(\mathrm{v} / \mathrm{m}) \pm 0.049$, which is an amount almost equal to the value mentioned in the literature.

In a 2000 study, Weidner MS and Sigwart K mention that ginger is classified as safe [44]. Chrubasik et al. [2005] reported in a literature review that the efficacy of ginger as an antiemetic is only confirmed in the states of nausea and vomiting during pregnancy [12]. Also, from a meta-analysis which included ten randomized 
FARMACIA, 2020, Vol. 68, 2

trials published in 2018, the authors concluded that ginger administered per os in different supplements may reduce postoperative nausea and vomiting [43]. In a 2008 review of Ali BH and colleagues, it was appreciated that ginger and many chemical constituents of ginger essential oil have remarkable antioxidant properties. Thus, the traditional use of ginger is scientifically based and is recommended for the prevention of metabolic and degenerative diseases associated with oxidative processes in the body $[1,3,18,39]$. Antioxidant activity

The scavenger capacity for the essential oil obtained from Zingiberis rhizoma purchased from the Romanian market, originating from China, has an IC50 $=30.72$ $\mu \mathrm{L} / \mathrm{mL}$, as shown in Table II.

Table II

Scavenger DPPH capacity and IC50 of Zingiberis rhizoma essential oil

\begin{tabular}{|c|c|c|c|}
\hline Sample of essential oil in acetone & Concentration $(\boldsymbol{\mu} \mathbf{L} / \mathbf{m L})$ & \% scavenger DPPH & \multirow{2}{*}{ IC 50 $(\boldsymbol{\mu L} / \mathbf{m L})$} \\
\hline Dilution 1 & 40 & 65.36 & \multirow{3}{*}{30.72} \\
Dilution 2 & 20 & 33.35 & \multirow{2}{*}{} \\
\hline Dilution 3 & 10 & 12.66 & 8.82 \\
\hline Dilution 4 & 5 & \\
\hline
\end{tabular}

The assessment of radical scavenging ability using the DPPH method has been performed on ginger essential oil by several authors. Norri et al. showed that the antioxidant activity is negligible [27].

Yeh et al. [45] show that EC50 values for extracts from two ginger rhizomes were in the range of 2.81 $5.57 \mathrm{mg} / \mathrm{mL}$, and the same authors indicate that the extracts showed a relatively effective ability of scavenging DPPH radicals.

Sacchetti et al. [33] showed that ginger essential oil reduced the concentration of DPPH free radicals by about $55 \%$.

Teerarak M, Laosinwattana $\mathrm{Ch}$ [41] showed that using ginger essential oil may represent an effective defence against free radical attack, possibly through a mechanism that maintains antioxidant activity at critical locations in the cell.

Antifungal activity

The disc diffusion test of the sensitivity of fungal strains isolated from the environment (Fonseceae sp. and Penicillium chrysogenum) to ginger essential oil was a preliminary study in our research project. The observations showed total growth inhibition for both fungal cultures in the first 5 - 7 days of the study (Figure 2a, Figure 2b and Table III), compared to the control plates (Figures 2e and 2f).

After prolonging the exposure time to over 10 days, the regrowth of the fungi became evident (Figures 2c and $2 \mathrm{~d}$ ). A slow growth was recorded for Fonsecaea $s p$. while normal colony growth was observed in the plates with strains of Penicillium chrysogenum (Tabel III).

The 10 days incubation period with visible antifungal effect (Figure 2) was correlated with the application of Zingiberis rhizoma essential oil because the formation of the fungi colonies was macroscopically visible from the $2^{\text {nd }}$ day for Penicillium and from the $5^{\text {th }}$ day for Fonsecaea, in the control samples.
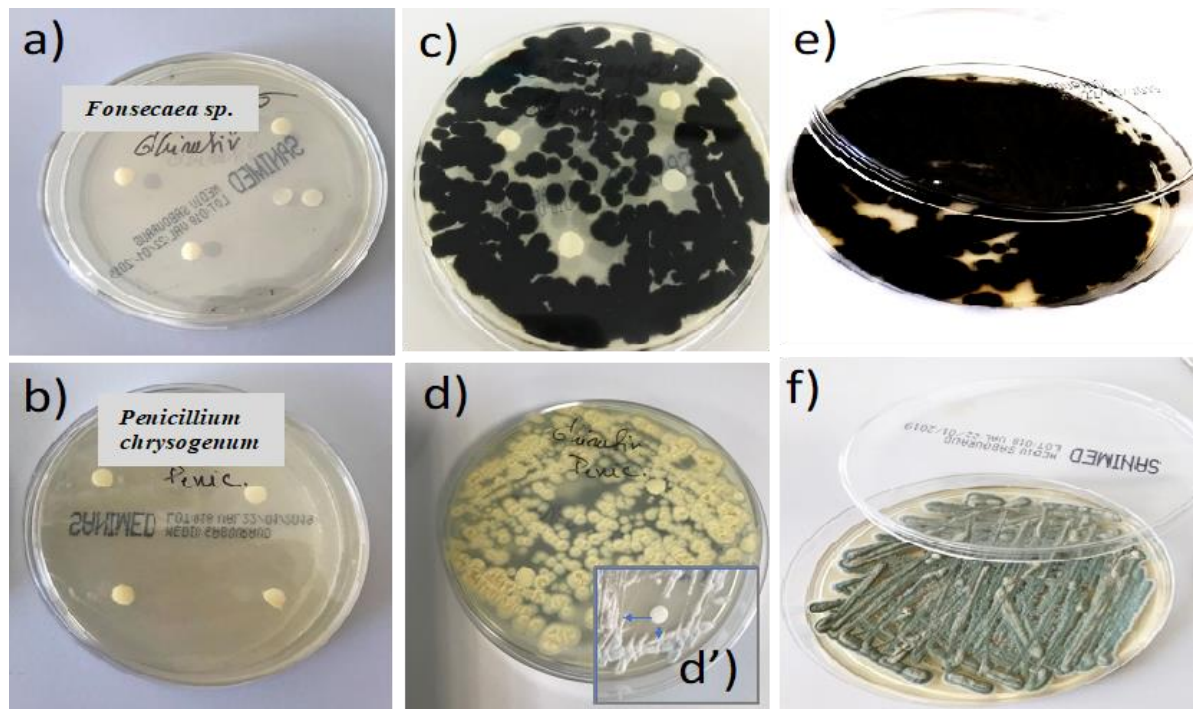

Figure 2.

Antifungal activity of Zingiberis rhizoma essential oil on Fonsecaea sp. and Penicillium chrysogenum strains: a, b-samples between 5 - 7 days; c, d - samples after 10 days; d'-zone of inhibition; e, f - control at 5 - 7 days 
FARMACIA, 2020, Vol. 68, 2

The growth inhibitive performance of ginger essential oil was determined by calculating the percentage of colonies of visible fungi found in control and experimental conditions. The method was adapted from airborne or surface fungi assay techniques [15]. This evaluation, which was done according to the NMAM 0800 standard method [15, 22], recorded an antifungal activity of $100 \%$ in the first 5-day period, which is a significant result for a preliminary screening. The inhibitory action of the Zingiberis rhizoma essential oil began to decline after the exposure time was extended

to 15 days, the evaluation specifying $23.8 \pm 1.2 \%$ for Fonsecaea sp. and $10 \pm 0.5 \%$ for Penicillium chrysogenum.

Antifungal activity in the areas surrounding the paper discs with Zingiberis rhizoma essential oil was still noticeable after 15 days. For instance, the inhibition zones around the discs measured $11 \pm 2 \mathrm{~mm}$ in the plates where ginger essential oil was applied to Fonsecaea $s p$. cultures, respectively $4.5 \pm 0.5 \mathrm{~mm}$ in plates where ginger essential oil was applied to Penicillium chrysogenum fungal strains (Table III).

Table III

Preliminary screening for antifungal action of Zingiberis rhizoma essential oil

\begin{tabular}{|c|c|c|c|c|}
\hline Fungus & $\begin{array}{c}\text { I } \\
5-7 \text { days }\end{array}$ & $\begin{array}{c}\text { Effect } \\
\text { II } \\
\mathbf{1 0}-\mathbf{1 5} \text { days }\end{array}$ & $\begin{array}{c}\text { III } \\
16-20 \text { days }\end{array}$ & $\begin{array}{c}\text { Zone of inhibition } \\
\text { diameter } \\
(\mathbf{m m})\end{array}$ \\
\hline Fonseceae sp. & - & -+ & ++ & $11 \pm 2$ \\
\hline Penicillium chrysogenum & - & +- & ++ & $4.5 \pm 0.5$ \\
\hline
\end{tabular}

The analysed strains are present in the environment and their assessment adds new information to the literature on the importance of essential oils in fighting fungal contamination. In similar studies, oregano, thyme and clove essential oils have also had an inhibitory effect on five different fungal strains, including Penicillium chrysogenum. Nevertheless, the way essential oils act depends on the fungal species and the concentration used in the test [31].

Given that such an ability to inhibit pathogenic fungi in humans represents an opportunity with implications on public health, ginger essential oil may prove useful in prevention measures aimed at limiting the dispersion of such pathogens.

For example, Fonsecaea sp. includes 3 known species whose pathogenic effect is triggered by touching or encountering contaminated surfaces. Avoiding contamination prevents the occurrence of chromoblastomycosis disease caused by Fonsecaea monophora, which is associated with brain diseases as well [34, 40].

The total inhibition of these strains for several days may be the premise for the development of some techniques by which a natural product can annihilate the dispersal of the fungus in public spaces or in heavily circulated areas.

In addition, the species analysed in this study are contamination agents found on works of art and/or exterior surfaces of historical monuments [35]. The source of this contamination can be man and vice versa, and such contamination is associated with interactions and implications with unknown risk.

As a result, the finding of methods for the application of prolonged release agents containing ginger essential oil can prevent the biodegradation and deterioration of art works and/or historical monuments through the impact of fungal colonization. Ginger essential oil could also have a role in protecting people in areas where the fungal distribution sources are present.

\section{Conclusions}

Zingiberis rhizoma commercialized on the Romanian market is rich in essential oil. Ginger belongs to the nutraceuticals category and represents, besides a highly appreciated spice, a possible remedy in the prevention and treatment of diseases caused by oxidative stress. Antifungal activity tested on two fungal strains in an isolated environment indicated a significant effect in both of the analysed species and may be a premise for the development of protocols for the prevention and halt of the spread of fungal species, which could contribute to the reduction of associated public health risks.

Based on the presented results, ginger essential oil has the potential to become technologically useful as a natural preventative antifungal agent.

\section{Conflict of interest}

The authors declare no conflict of interest.

\section{References}

1. Ali BH, Blunden G, Tanira MO, Nemmar A, Some phytochemical, pharmacological and toxicological properties of ginger (Zingiber officinale Roscoe): a review of recent research. Food Chem Toxicol., 2008; 46(2): 409-420.

2. Amalraj A, Haponiuk JT, Thomas S, Gopi S, Preparation, characterization and antimicrobial activity of polyvinyl alcohol/gum Arabic/chitosan composite films incorporated with black pepper essential oil and ginger essential oil. Int J Biol Macromol., 2020; 151: 366-375.

3. Aryaeian N, Shahram F, Mahmoudi M, Tavakoli H, Yousefi BT, Arablou T, Karegar SJ, The effect of ginger supplementation on some immunity and inflammation intermediate genes expression in patients with active rheumatoid arthritis. Gene, 2019; 698: 179-185. 
FARMACIA, 2020, Vol. 68, 2

4. Badea ML, Delian E, In vitro antifungal activity of the essential oils from Artemisia spp. L. on Sclerotinia sclerotiorum. Rom Biotech Lett., 2014, 19(3), 93459352.

5. Baldin VP, de Lima Scodro BR, Fernandez CMM, Ieque AL, Caleffi-Ferracioli KR, Dias Siqueira VL, de Almeida AL, Gonçalves JE, Garcia Cortez DA, Cardoso RF, Ginger essential oil and fractions against Mycobacterium spp. J Ethnopharmacol., 2019; 244: 1-7.

6. Bellotti N, Salvatore L, Deyá C, Del Panno MT, del Amo B, Romagnoli R, The application of bioactive compounds from the food industry to control mold growth in indoor waterborne coatings. Colloids Surf B Biointerfaces, 2013; 104: 140-144.

7. Bonilla J, Poloni T, Lourenço RV, Sobral PJA, Antioxidant potential of eugenol and ginger essential oils with gelatin/chitosan films. Food Biosci., 2018; 23: 107-114.

8. Bucur L, Stanciu G, Istudor V, The GC-MS analysis of Elaeagnus angustifolia L. flowers essential oil. Rev Chim Bucharest, 2007; 58(11): 1027-1029.

9. Bucur L, Ţarălungă Gh, Schroder V, The betalains content and antioxidant capacity of red beet (Beta vulgaris L. subsp. vulgaris) root. Farmacia, 2016; 64(2): 198-201.

10. Buiuc D, Neguţ M, Treatise on clinical microbiology, $3^{\text {rd }}$ Edition, completed and revised. Medicală Publishing house, Bucureşti, 2009; 394-405, 995-1028 (available in Romanian).

11. Buşuricu F, Negreanu-Pîrjol T, Popescu A, Margariti D, Lupu C, Schröder V, Tomoş S, The evaluation of wines antioxidant activity. J Environ Prot Ecol., 2013; 14(4): 1828-1835.

12. Chrubasik S, Pittler MH, Roufogalis BD, Zingiberis rhizoma: a comprehensive review on the ginger effect and efficacy profiles. Phytomedicine, 2005; 12(9): 684-701.

13. De Lira Mota KS, De Oliveira Pereira F, De Oliveira WA, Lima IO, De Oliveira Lima E., Antifungal activity of Thymus vulgaris L. essential oil and its constituent phytochemicals against Rhizopus oryzae: Interaction with ergosterol. Molecules, 2012; 17(12): 14418-14433.

14. Ding SH, An KJ, Zhao CP, Li Y, Guo YH, Wang ZF, Effect of drying methods on volatiles of Chinese ginger (Zingiber officinale Roscoe). Food Bioprod Process, 2012; 90(3): 515-524.

15. Er CM, Sunar NM, Leman AM, Othman N, Direct growth inhibition assay of total airborne fungi with application of biocide-treated malt extract agar. MethodsX, 2015; 2: 340-344.

16. Evans WC, Trease and Evans Pharmacognosy $16^{\text {th }}$ ed., WB Saunders, Edinburgh, 2009; 289-292.

17. Freire JCP, Junior JKO, Silva DF, de Sousa JP, Guerra FQS, Lima EO, Antifungal activity of essential oils against Candida albicans strains isolated from users of dental prostheses. Evid Based Complement Alternat Med., 2017; 2017: 1-9.

18. Funk JL, Fryea JB, Oyarzoa JN, Chena J, Zhangb H, Timmermann BN, Anti-inflammatory effects of the essential oils of ginger (Zingiber officinale Roscoe) in experimental rheumatoid arthritis. PharmaNutrition, 2016; 4(3): 123-131.
19. Hu J, Zhang Y, Xiao Z, Wang X, Preparation and properties of cinnamon - thyme - ginger composite essential oil nanocapsules. Ind Crops Prod., 2018; 122: 85-92.

20. Jantan I, Yassin MSM, Chin CB, Chen LL, Sim $\mathrm{NL}$, Antifungal activity of the essential oils of nine Zingiberaceae species. Pharm Biol., 2003; 41(5): 392-397.

21. Kostici R, Biţă A, Bejenaru LE, Bejenaru C, Popescu FD, Mogoşanu GD, Popescu F, HPTLC quantification of polyphenolic acids and antioxidant activity of Polygonum hydropiper 1. species from Romanian flora. Farmacia, 2019; 67(6): 1005-1010.

22. Lindsley WG, Green BJ, Blachere FM, Martin SB, Law BF, Jensen PA, Schafer MP, NIOSH Sampling and characterization of bioaerosols NIOSH Manual of Analytical Methods (NMAM), $5^{\text {th }}$ ed. Chapter BA, 2017; 1-115.

23. Lucca LG, Matos SP, Borille BT, de O Dias D, Teixeira HF, Veiga VF Jr, Limberger RP, Koester LS, Determination of $\beta$-caryophyllene skin permeation/ retention from crude copaiba oil (Copaifera multijuga Hayne) and respective oil based nanoemulsion using a novel HS-GC/MS method. J Pharm Biomed Anal., 2015; 104: 144-148.

24. Mesomo MC, Corazza ML, Ndiaye PM, Dalla Santa OR, Cardozo L, Scheer A. de P, Supercritical $\mathrm{CO}_{2}$ extracts and essential oil of ginger (Zingiber officinale R.): Chemical composition and antibacterial activity. J Supercrit Fluid, 2013; 80: 44-49.

25. Mi H, Guo X, Li J, Effect of 6-gingerol as natural antioxidant on the lipidoxidation in red drum fillets during refrigerated storage. $L W T, 2016 ; 74: 70-76$.

26. Moghaddam M, Mehdizadeh L, Essential oil and antifungal therapy, recent trends in antifungal agents and antifungal therapy, Springer, New Delhi, 2016, 29-74.

27. Noori S, Zeynali F, Almasi H, Antimicrobial and antioxidant efficiency of nanoemulsion-based edible coating containing ginger (Zingiber officinale) essential oil and its effect on safety and quality attributes of chicken breast fillets. Food Control, 2018; 84: 312-320.

28. Nurhazwani MH, Saidatul HS, Nor Azah MA, Azrina A, Mailina J, Norulaiman Y, Wan NM, Mohammad FZP, Quality control of Zingiber Officinale oils in product formulations. J Teknol., 2015; 77(3): 39-42.

29. Patel RM, Jasrai YT, Evaluation of fungitoxic potency of Piper betel L. (Mysore variety) leaf extracts against eleven phyto- pathogenic fungal strains. Cibtech $J$ Bio-Protocols, 2013; 2(2): 21-28.

30. Pîrvu L, Sha'at F, Păvăloiu R, Udeanu DI, Albu B, Studies on Acinos alpinus 1.: polyphenols and terpenoids compounds profile, antimicrobial activity, antioxidant effect and release experiments on the ethanol and propylene glycol extracts. Farmacia, 2019; 67(6): 1025-1033.

31. Puskarova A, Buckova M, Krakova L, Pangallo D, Kozics K, The antibacterial and antifungal activity of six essential oil and their cyto/genotoxicity to human HEL 12469 cells. Sci Rep., 2017; 7: 1-11.

32. Ravichandran K, Thaw Saw NMM, Mohdaly AAA, Gabr AMM, Kastell A, Riedel H, Cai Z, Knorr D, Smetanska I, Impact of processing of red beet on 
betalain content and antioxidant activity. Food Res Int., 2013; 50(2): 670-675.

33. Sacchetti G, Maietti S, Muzzoli M, Scaglianti M, Manfredini S, Radice M, Bruni R, Comparative evaluation of 11 essential oils of different origins functional antioxidants, antiradicals and antimicrobials in foods. Food Chem., 2005; 91(4): 621-632.

34. Salgado CG, da Silva JP, Diniz JA, da Silva MB, da Costa PF, Teixeira C, Salgado UI, Isolation of Fonsecaea pedrosoi from thorns of Mimosa pudica, a probable natural source of chromoblastomycosis. Rev Inst Med Trop Sao Paulo, 2004; 46(1): 33-36.

35. Schroder V, Carutiu Turcanu D, Honcea A, Ion RM, Microscopical methods for the in situ investigation of biodegradation on cultural heritage. Advanced Methods and new Materials for Cultural Heritage Preservation. London, UK., 2019; Chapter 5, 79-96.

36. Scorzoni L, Benaducci T, Almeida AMF, Silva DHS, Bolzani VS, Gianinni MJSM, The use of standard methodology for determination of antifungal activity of natural products against medical yeasts Candida sp. and Cryptococcus sp. Braz J Microbiol., 2007, 38(3): 391-397.

37. Sharifi-Rad M, Varoni EM, Salehi B, Sharifi-Rad J, Matthews KR, Ayatollahi SA, Kobarfard F, Ibrahim SA, Mnayer D, Zakaria ZA, Sharifi-Rad M, Yousaf Z, Iriti M, Basile A, Rigano D, Plants of the genus Zingiber as a source of bioactive phytochemicals: from tradition to pharmacy. Molecules, 2017; 22: 1-20.

38. Shukla A, Naik SN, Goud VV, Das C, Supercritical $\mathrm{CO}_{2}$ extraction and online fractionation of dry ginger for production of high-quality volatile oil and gingerols enriched oleoresin. Ind Crops Prod., 2019; 130: 352-362.
39. Srinivasan K, Ginger rhizomes (Zingiber officinale): A spice with multiple health beneficial potentials. Pharma Nutrition, 2017; 5(1):18-28.

40. Sun J, Najafzadeh MJ, Vicente V, Xi L, de Hoog GS, Rapid detection of pathogenic fungi using loopmediated isothermal amplification, exemplified by Fonsecaea agents of chromoblastomycosis. J Microbiol Methods, 2010; 80(1): 19-24.

41. Teerarak M, Laosinwattana Ch, Essential oil from ginger as a novel agent in delaying senescence of cut fronds of the fern (Davallia solida (G. Forst.) Sw.). Postharvest Biol Technol., 2019; 156: 1-8.

42. Tongnuanchan P, Benjakul S, Prodpran T, Physicochemical properties, morphology and antioxidant activity of film from fish skin gelatin incorporated with root essential oils. J Food Eng., 2013; 117: 350-360.

43. Tóth B, Lantos T, Hegyi P, Viola R, Vasas A, Benkö R, Gyöngyi Z, Vincze Á, Csécsei P, Mikó A, Hegyi D, Szentesi A, Matuz M, Csupor D, Ginger (Zingiber officinale): An alternative for the prevention of postoperative nausea and vomiting. A meta-analysis. Phytomedicine, 2018; 50: 8-18.

44. Weidner MS, Sigwart K, The safety of a ginger extract in the rat. J Ethnopharmacol., 2000; 73(3):513-520.

45. Yeh HY, Chuang CH, Chen HC, Wan CJ, Chen TL, Lin LY, Bioactive components analysis of two various gingers (Zingiber officinale Roscoe) and antioxidant effect of ginger extracts. $L W T, 2014 ; 55(1)$ : 329-334.

46. ***EN ISO 14698-1: - Cleanrooms and associated controlled environments - Biocontamination control Part 1: General principles and methods, 2003.

47. ***European Pharmacopoeia, 9.0 edition, volume I, EDQM Council of Europe, Strassbourg, 2017; 1367. 